\title{
Study of a contact between two chromosomally monomorphic races of Sorex araneus L. (common shrew)
}

\author{
STANISŁAW FEDYK, MAŁGORZATA ZAJKOWSKA \& WŁODZIMIERZ CHȨTNICKI \\ Institute of Biology, Warsaw University Bialystok Branch, Swierkowa 20B, 15-950 Białysok, Poland
}

\begin{abstract}
One hundred and twelve specimens of the common shrew from 21 populations in NE Poland were studied from an area of contact between chromosomal race II (metacentric chromosomes: hi, ko, $g m, n p)$ and race VII $(k i, h n, g r, m p)$. No direct contact was found between the races in the study area; there were no mixed or hybrid populations. The shortest distance between populations of the two races was $1.2-1.6 \mathrm{~km}$. Possible explanations for this pattern of the races' disjunction are discussed.
\end{abstract}

Keywords: chromosomal races, hybrid zone, Robertsonian rearrangements, Sorex araneus.

\section{Introduction}

There is a great diversity of karyotypes in Sorex araneus as a result of Robertsonian rearrangements of a series of 12 autosomal arms $(g-r$; arms labelled according to Searle et al. (1991)). There are two aspects of this diversity: intrapopulational - Robertsonian polymorphism occurs over a large area of the species range - and interpopulational - the occurrence of separate races characterized by metacentrics with differing combinations of autosome arms in the $g-r$ series (Fredga \& Nawrin, 1977; Searle, 1988).

In NE Poland (Fig. 1b), seven basic chromosomal races of $S$. araneus have been reported so far (Fredga \& Nawrin, 1977; Fedyk, 1980, 1986; Wójcik \& Fedyk, 1985; Fedyk \& Leniec, 1987) and labelled with Roman numerals I-VII (Fedyk, 1986). Studies of a hybrid zone between races II and IV have shown that shrews provisionally described as race III are in fact II/IV interracial recombinants and that they never occur as pure forms outside the hybrid zone (Fedyk et al., 1991). Nevertheless, when local polymorphic and monomorphic variants are considered, as many as 10 specific combinations of metacentric chromosomes (Fedyk, 1987) can be distinguished in northern Poland (Table 1).

Contact zones among $S$. araneus have been studied in the U.K. (Searle, 1986; Mercer \& Searle, 1991), Sweden (Fredga, 1987), Poland (Fedyk, 1986, unpublished data; Fedyk et al., 1991), Switzerland (Hausser et al., 1991) and Siberia (Aniskin \& Lukianova, 1989). Most studies have been concerned with contacts between polymorphic races. In these contact zones post-hybridization modifications enhancing fertility in hybrid populations were observed. These modifications may include at least two known phenomena: (i) maximization of the frequency of acrocentric chromosomes in the contact zone (Searle, 1986); or (ii) maximization of frequency of interchromosomal recombinants in the centre of the hybridization zone (Fedyk et al., 1991). The occurrence of maximum frequencies of acrocentric chromosomes, also known as an acrocentric buffer zone (Fedyk, 1986; Halkka et al., 1987 ), is possible only in the case of a contact between two polymorphic races. Interchromosomal recombinants, however, may arise in the centre of a hybridization zone in which at least two independently segregating meiotic complexes are produced among the hybrids (for details see Fedyk et al., 1991).

For the present study a sector of a II/VII inter-racial contact zone was chosen, where it was impossible for any of the known types of post-hybridization modification to arise. The absence of Robertsonian polymorphism prevents the occurrence of an acrocentric buffer zone. On the other hand, during meiosis potential hybrids of homozygotes of races II and VII should produce a single chain with a decavalent configuration (Fedyk, 1987) which rules out recombination between diagnostic metacentric chromosomes of the two races. 
Table 1 Chromosomal races of Sorex araneus: races and variants found in NE Poland

\begin{tabular}{|c|c|c|c|c|c|c|c|}
\hline \multirow{2}{*}{$\frac{\text { Origin }}{\text { WEpg } \dagger}$} & \multirow{2}{*}{ Race } & \multirow{2}{*}{$\begin{array}{l}\text { Variant } \S \S \\
\text { I a } \\
\text { I pol }\end{array}$} & \multicolumn{4}{|c|}{ Diagnostic metacentrics } & \multirow{2}{*}{$\begin{array}{l}\text { References } \\
\text { Wójcik \& Fedyk, 1985; Fedyk, } 1986 \\
\text { Fedyk, } 1986\end{array}$} \\
\hline & & & $\begin{array}{l}h i \\
h i\end{array}$ & $\begin{array}{l}\text { koा } \\
\text { koा, }\end{array}$ & $\overline{g m \pi}$ & - & \\
\hline & II & $\begin{array}{l}\text { II pol } \\
\text { II mon }\end{array}$ & $\begin{array}{l}h i \\
h i\end{array}$ & $\begin{array}{l}\text { ko, } \\
\text { ko, }\end{array}$ & $\begin{array}{l}g m \pi, \\
g m,\end{array}$ & $\begin{array}{l}n p \pi \\
n p\end{array}$ & $\begin{array}{l}\text { Fedyk, } 1986 \\
\text { This paper }\end{array}$ \\
\hline $\begin{array}{l}\text { Hybrid } \\
\text { origin } \ddagger\end{array}$ & $\begin{array}{l}\text { IV } \\
\text { V } \\
\text { VI }\end{array}$ & $\begin{array}{l}\text { IV pol } \\
\text { V pol } \\
\text { VI pol }\end{array}$ & $\begin{array}{l}h k \\
h k \\
k i \pi\end{array}$ & $\frac{i o \pi,}{h q \pi}$ & $\begin{array}{l}g r \pi, \\
g r \pi \\
g r \pi\end{array}$ & $\begin{array}{l}m n \pi \\
m n \pi \\
m n \pi\end{array}$ & $\begin{array}{l}\text { Fedyk, 1986; Wójcik, } 1986 \\
\text { Fedyk, 1986 } \\
\text { Fedyk, 1986, Wójcik, } 1986\end{array}$ \\
\hline $\mathrm{EEPg} \S$ & VII & $\begin{array}{l}\text { VII mon? } \\
\text { VII pol } \\
\text { VII mon }\end{array}$ & $\begin{array}{l}k i, \\
k i, \\
k i\end{array}$ & $\begin{array}{l}-\overline{-} \\
h n \pi\end{array}$ & $\begin{array}{l}g r \\
g r \pi \\
g r\end{array}$ & $\begin{array}{l}- \\
\mathrm{mp} \pi \\
m p\end{array}$ & $\begin{array}{l}\text { Fedyk, } 1987 \\
\text { Fredga \& Nawrin 1977; Fedyk, } 1980 \\
\text { This paper }\end{array}$ \\
\hline
\end{tabular}

†West European phylogenetic group, following Searle (1984b). ¥After Fedyk (1987).

$\S$ East European phylogenetic group, following Searle (1984b). $\S \S$ Polymorphic (pol) and monomorphic (mon) variants of races. TPolymorphic combinations of chromosome arms.

This study has parallels with the analysis carried out on a contact zone between the Oxford and Aberdeen homozygous races in Scotland (Mercer \& Searle, 1991).

\section{Materials and methods}

\section{Study area}

The valleys of the lower reaches of the Bug and Narew Rivers converge in a lowland area of eastern Poland (Mazovian Lowland). This is a region characterized by slightly diversified relief (height varies between $60 \mathrm{~m}$ and $150 \mathrm{~m}$ above sea level). The humid habitats preferred by shrews directly adjoin rivers; these are the flood meadow terraces. In the valley of the Narew River the flood terrace is larger than that of the Bug valley. The flood terraces rapidly change to sand dune terraces, now covered with coniferous forest or arable land. The dune terraces are at least $2 \mathrm{~m}$ above the flood terrace and hence are protected from flooding. The flood terrace is a labile habitat: during periods of high water level it is flooded and in some meadows there are high groundwater levels all year round. This prevents permanent colonization of the area by small mammals.

\section{Animal collection and characteristics of capture sites}

The ranges of races II and VII were determined within a $50 \mathrm{~km}$ strip. Shrews were collected in 1986 and 1987 at 12 sites in the valleys of the Bug and Narew Rivers (Fig. 1c).
Detailed studies on the racial contact were conducted in 1991 at 12 sites situated along a $6 \mathrm{~km}$ strip of the Fiszor River (Fig. 1d). The collection sites were situated at reasonably regular intervals. The attempt was to locate them in habitats most suitable for $S$. araneus. In spite of this, these habitats varied substantially in their trappability coefficients for $S$. araneus and in the composition of the associated species group (Table 2). The animals were trapped in metal cones lined with moss, with food provided. The cones were checked every $2 \mathrm{~h}$ round the clock.

The Stopsk I and VII sites were located in a very narrow (about $50 \mathrm{~m}$ ) strip of humid meadows. The groundwater level approaches $10 \mathrm{~cm}$ to $5 \mathrm{~cm}$ below ground surface. During periods of high groundwater level (especially in spring) this meadow is completely flooded. No animals were collected at either site. No doubt it is a habitat unsuitable for colonization by shrews. The Stopsk II site was in reeds in a very marshy old river meander. In such habitats $S$. araneus usually occurs in great numbers. In this case the absence of $S$. araneus in the animals collected might have been caused by improper arrangement of the traps in excessively humid places; this is supported by the fact that $150 \mathrm{~m}$ from this site, at Stopsk III situated in a narrow strip of alder forest, all three species of Insectivora and C. glareolus were collected. The Fiszor site was in a similar habitat (river bank alder forest); the composition of the species collected here was the same as at Stopsk III. Słopsk V was situated along a drainage ditch in a meadow used as pasture. Only $S$. araneus and Micromys minutus were collected here. The Drȩszew, Stopsk VI and IV sites are far from the river bed and 


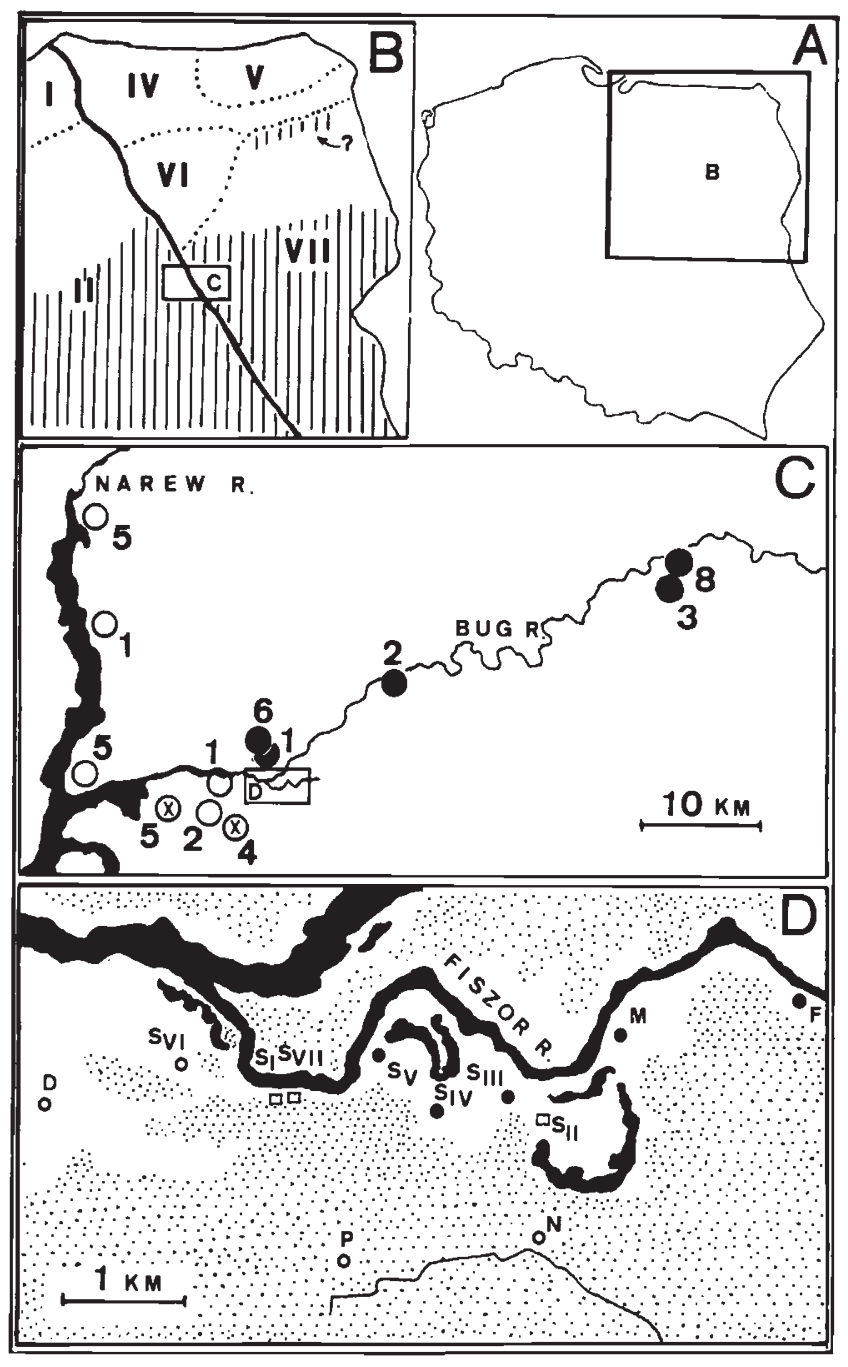

Fig. 1 Distribution of chromosome races of the common shrew in NE Poland. (a) Ouțline of Poland. (b) Ranges of basic chromosomal races in NE Poland. The boundary between the West European and East European phylogenetic groups is marked by a solid line. The ranges of local chromosome races are marked by dotted lines. Shaded areas indicate monomorphic zones of races II and VII. (c) Distribution of race II (O) and race VII (-) in the valleys of the Bug and Narew; crosses denote populations containing $n / p$ heterozygotes; numbers indicate sample sizes. (d) Contact zone of race II (O) and race VII $(\bullet)$. The sites at which no $S$. araneus were collected are marked by rectangles. Dotted areas are sand dune terraces. Population code: D, Drȩszew; P, Powłóczki; N, Niegów; M, Młynarze; F, Fiszor; $S_{1}-S_{V I I}$, Słopsk I-VII.

are therefore not susceptible to flooding. There are diversified habitats here (a mosaic of alder forest, meadow and scrubs). The greatest variety of species was collected at these three sites. The Niegów and Powłoczki sites are in isolated, more humid areas (alder forest with scrubs surrounded by coniferous woods) in the area of a dune terrace. At these sites the number of individuals of $S$. araneus collected was low and the species compositions were similar (Table 2).

Viewing only the trappability coefficient for $S$. araneus (Table 2) it may be stated that in the contact zone of races II and VII there is a clear population density gradient connected with habitat conditions. Between Słopsk VI and Słopsk V there is about a $1 \mathrm{~km}$ strip of unfavourable habitats where the density of $S$. araneus is zero or minimal (Fig. 1d).

\section{Karyological methods}

Chromosome preparations from the spleen were made by standard methods and stained with Giemsa reagent after treatment with trypsin (Seabright, 1971).

\section{Results}

The studies in 1986 and 1987 demonstrated that the shrews from seven sites lying in the fork of the Narew and Bug Rivers belong to race II (Fig. 1c). At five sites only homozygous shrews with the diagnostic chromosomes $h i, k o, g m$ and $n p$ were captured. One individual in each of the remaining two populations was a $n / p$ heterozygote. Five other populations located eastward in the Bug River valley belong to race VII (Fig. $1 c)$, with the diagnostic metacentrics $i k, h n, g r$ and $m p$. In the latter populations Robertsonian polymorphism was not found.

The results of our detailed studies of the contact between races II and VII are presented in Table 3. In this case samples were collected along a $6 \mathrm{~km}$ strip (Fig. 1d). Along this transect, the Dresszew and Słopsk VI populations belong to race II. At the Drȩszew site, 18 shrews homozygous for metacentrics (Fig. 2) and one shrew homozygous for the acrocentrics $n$ and $p$ were captured. In the Słopsk VI population one of the specimens was a $j / l$ heterozygote. On the dune terrace, race II shrews were caught further to the east than on the main transect. These were the isolated populations of Powłóczki and Niegów (Fig. 1d). The remaining populations from the main transect (Stopsk V, IV, III, Młynarze and Fiszor) belong to race VII (Fig. 1d, Table 3). All the shrews of race VII were homozygotes (Fig. 3). At Stopsk I, VII and II, no specimens of S. araneus were collected. None of the nine sites under study yielded shrews of both races (Table 3 ). The shortest linear distances between sites where specimens of pure races II and VII were captured are: Stopsk VI-Stopsk V, 1.6 km; Powłóczki-Słopsk IV, 1.4 km; and NiegówSłopsk III, 1.2 km (Fig. 1d). 
Table 2 Numbers of small mammals collected in 1991 around the contact between races II and VII.

\begin{tabular}{lrccccccc}
\hline Population & $\begin{array}{c}\text { Trap- } \\
\text { nights }\end{array}$ & \multicolumn{1}{c}{ S. ara } & S. min & N. fod & M. sp & C. gla & M. min & S. bet \\
\hline Drȩszew & 172.5 & $22(0.13)$ & $26(0.15)$ & $1(0.01)$ & $7(0.04)$ & $10(0.06)$ & $2(0.01)$ & - \\
Słopsk VI & 190.5 & $16(0.08)$ & $8(0.04)$ & - & $6(0.03)$ & $8(0.04)$ & $1(0.005)$ & - \\
Słopsk I & 20.3 & - & - & - & - & - & - & - \\
Słopsk VII & 58.9 & - & - & - & - & - & - & - \\
Powłóczki & 150.7 & $4(0.03)$ & $6(0.04)$ & - & - & $6(0.04)$ & - & - \\
Niegów & 54.7 & $1(0.02)$ & $2(0.04)$ & - & - & $1(0.02)$ & - & - \\
Słopsk V & 43.1 & $2(0.05)$ & - & - & - & - & $2(0.05)$ & - \\
Słopsk IV & 272.6 & $18(0.07)$ & $7(0.03)$ & $3(0.01)$ & $1(0.004)$ & $1(0.004)$ & $1(0.004)$ & $1(0.004)$ \\
Słopsk III & 103.0 & $6(0.06)$ & $2(0.02)$ & $3(0.03)$ & - & $1(0.01)$ & - & - \\
Słopsk II & 48.4 & - & $1(0.02)$ & - & - & $3(0.06)$ & - & - \\
Fiszor & 178.3 & $14(0.08)$ & $6(0.03)$ & $3(0.02)$ & - & $3(0.02)$ & - & - \\
\hline
\end{tabular}

[For each species the trappability coefficient (number of individual caught per trap-nights) is indicated in parentheses.] S. ara, Sorex araneus; S. min, Sorex minuts; N. fod, Neomys fodiens; M. sp; Microtus sp; C. gla, Clethrionomys glareolus; M. min, Micromys minutus; S. bet, Sicista betulina.
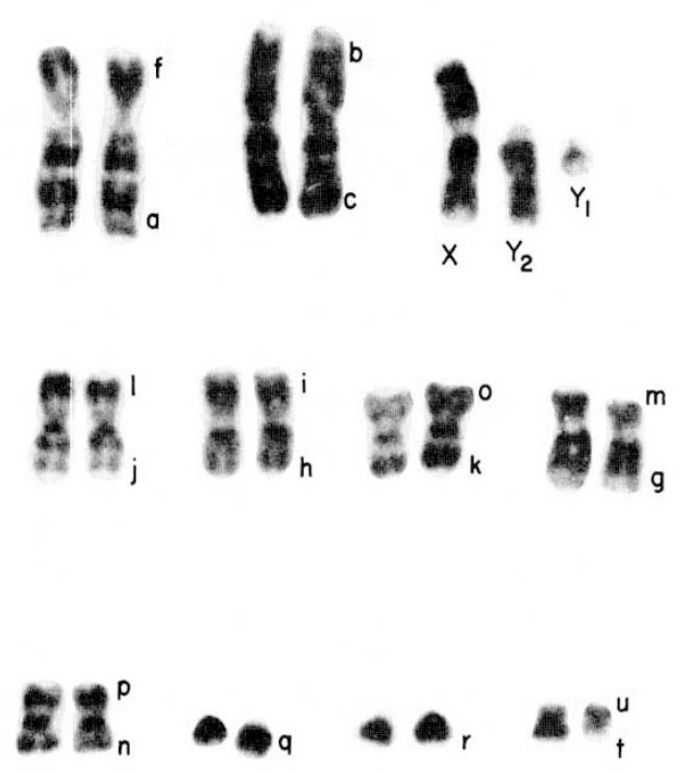
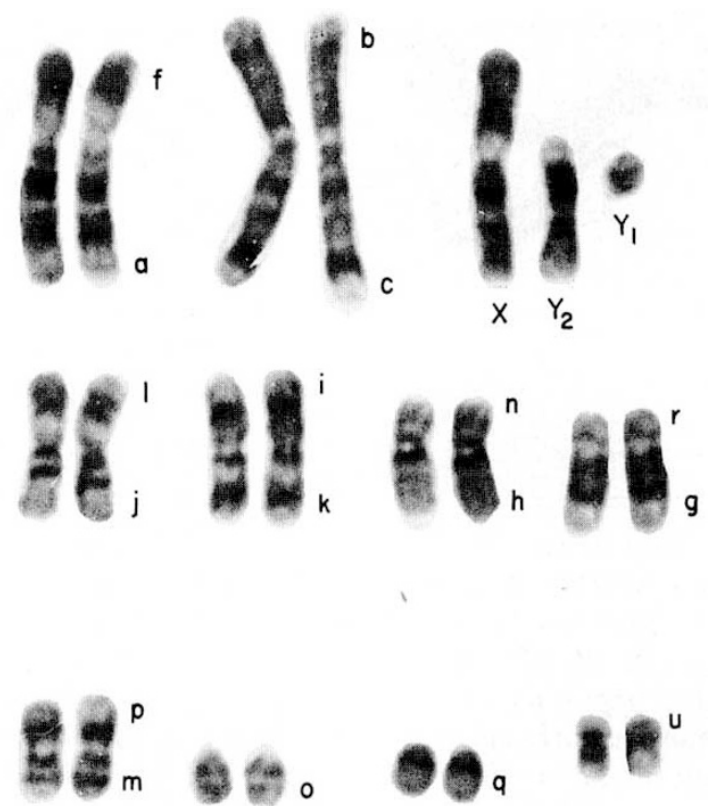

Fig. 2 G-banded karyotype of a race II shrew.

\section{Discussion}

This study suggests that in the area where races II and VII are monomorphic there is no direct contact between the races; no mixed populations were found. The pure populations were separated by $1-2 \mathrm{~km}$ of excessively wet habitats, unsuitable for permanent colonization by small mammals. On the other hand, the width of hybrid zone between the two polymorphic races Oxford and Hermitage is $10 \mathrm{~km}$ (Searle, 1986)
Fig. 3 G-banded karyotype of a race VII shrew.

and that between II and IV races as much as $16 \mathrm{~km}$ (Fedyk et al., 1991, unpublished data).

The presence of a 'demarcation zone' separating two races may be explained through a model of dispersal/ selection balance. Theoretically, under considerable pressure of selection against hybrids contact zones should not move far as they are readily trapped by regions of low density or even slight natural barriers to dispersal (Hewitt \& Barton, 1980). Probably the two races originally made contact further to the east of their 
Table 3 Frequencies of variable chromosomes at sites from the contact zone between races II and VII

\begin{tabular}{|c|c|c|c|c|c|c|c|c|c|c|c|}
\hline \multirow[b]{2}{*}{ Site } & \multirow[b]{2}{*}{ Code } & \multicolumn{9}{|c|}{ Frequency of metacentrics } & \multirow[b]{2}{*}{$N$} \\
\hline & & $h i$ & ko & $g m$ & $n p$ & $k i$ & $h n$ & $g r$ & $m p$ & $j l$ & \\
\hline Drȩszew & $\mathrm{D}$ & 1.00 & 1.00 & 1.00 & 0.95 & - & - & - & - & 1.00 & 19 \\
\hline Słopsk VI & $\mathrm{S}_{\mathrm{VI}}$ & 1.00 & 1.00 & 1.00 & 1.00 & - & - & - & - & 0.96 & 12 \\
\hline Powłóczki & $P$ & 1.00 & 1.00 & 1.00 & 1.00 & - & - & - & - & 1.00 & 3 \\
\hline Niegów & $\mathrm{N}$ & 1.00 & 1.00 & 1.00 & 1.00 & - & - & - & - & 1.00 & 1 \\
\hline Słopsk V & $\mathrm{S}_{\mathrm{V}}$ & - & - & - & - & 1.00 & 1.00 & 1.00 & 1.00 & 1.00 & 2 \\
\hline Słopsk IV & $S_{I V}$ & - & - & - & - & 1.00 & 1.00 & 1.00 & 1.00 & 1.00 & 12 \\
\hline Słopsk III & $\mathrm{S}_{\mathrm{III}}$ & - & - & - & - & 1.00 & 1.00 & 1.00 & 1.00 & 1.00 & 4 \\
\hline Młynarze $\dagger$ & M & - & - & - & - & 1.00 & 1.00 & 1.00 & 1.00 & 1.00 & 6 \\
\hline Fiszor & $\mathrm{F}$ & - & - & - & - & 1.00 & 1.00 & 1.00 & 1.00 & 1.00 & 10 \\
\hline
\end{tabular}

$\dagger 1986$ sample (S. Fedyk \& H. Leniec, unpublished data), all others collected in 1991.

present position, as suggested by the presence of race II shrews in the Powłóczki and Niegów populations (Fig. 1d). At meiosis I, hybrids should produce chains of 10 chromosomes: o/ok/ki/ih/hn/np/pm/mg/gr/r. Hybrids with large meiotic complexes have been obtained in $S$. araneus in breeding conditions (Searle, 1984a; Mercer et al., 1992) and they also occur under natural conditions (Aniskin \& Lukianova, 1989). Studies of heterozygous mice suggest that the probability of producing chromosomally balanced gametes is inversely proportional to the number of chromosomes within a meiotic complex (Capanna, 1975; Capanna et al., 1977; Gropp \& Winking, 1981; Gropp et al., 1982). This dependence has also been supported by studies of $S$. araneus hybrid zones: shrews characterized by short meiotic chains are much commoner than those with long chains (Searle, 1986, 1990; Fedyk et al., 1991). It may be supposed that as a result of significant hybrid unfitness the tension zone became trapped in an environmental sharp gradient at the present position in the Słopsk area.

Obviously a $1 \mathrm{~km}$ strip of unfavourable habitat is not a complete isolation barrier for a shrew. In Scandinavia, $S$. araneus has been shown to disperse $4 \mathrm{~km}$ (Tegelström \& Hansen, 1987). Also, an excessively humid habitat, although unsuitable for permanent colonization, may not constitute an obstacle to the exchange of individuals between races as it is known that shrews regularly colonize islands in lakes (Hanski, 1986; Hanski \& Kuitunen, 1986; Hanski et al., 1991). That shrews can swim long distances in quiet water has been demonstrated experimentally (Skarén, 1980) and it has also been shown that $S$. araneus is often the prey of carnivorous fish (Teplov, 1943).
Thus, it may be suggested that very wet habitats are not a complete barrier and that along with selection against hybrids they only serve to stabilize allopatric ranges. In this context the suggestion by Mercer \& Searle (1991) that a small river may constitute a boundary for the Oxford and Aberdeen races seems quite plausible.

\section{Acknowledgements}

B. Kosikowska, H. Leniec, M. Pietuchowska and A. Radulska assisted in laboratory and field work. We are grateful to Dr J. B. Searle for his comments on the manuscript and for improving the English. This study was sponsored under Grant CPBP 04.03/6 from the Polish Academy of Sciences, Grant RZL-894-MEN-90 from the Ministry of National Education and Grant BW-46 from Warsaw University.

\section{References}

ANISKIN, v. M. AND LUKIANOVA, I. v. 1989. Nowaja chromosomnaja rasa $\mathbf{i}$ analiz zony gibridizacii dwuch karioform Sorex araneus (Insectivora, Soricidae). Dokl. Akad. Nauk SSSR, 309, 1260-1262 (in Russian).

CAPANNA, E. 1975. Gametic aneuploidy in mouse hybrids. Chromosomes Today, 5, 83-89.

CAPANNA, E., CIVITELli, M. V. AND CRISTALDI, M. 1977. Chromosomal rearrangement, reproductive isolation and speciation in mammals. The case of Mus musculus. Boll. Zool., 44, 213-246.

FEDYK, S. 1980. Chromosome polymorphism in a population of Sorex araneus L. at Białowieźa. Folia Biol. (Kraków), 28, 83-120.

FEDYK, s. 1986. Genetic differentiation of Polish populations of Sorex araneus L. II. Possibilities of gene flow between 
chromosome races. Bull. Acad. Pol. Sci., Biol. Sci., 34, 161-171.

FEDYK, s. 1987. Hybrid origin of some local chromosome races of Sorex araneus. Abstract to the First International Meeting on the Population and Evolutionary Cytogenetics of Sorex araneus, Oxford, UK.

FEDYK, S. AND LENIEC, H. 1987. Genetic differentiation of Polish populations of Sorex araneus L. I. Variability of autosome arm combinations. Folia Biol. (Kraków), 35, 57-68.

FEDYK, S., CHETNICKI, w. AND BANASZEK, A. 1991. Genetic differentiation of Polish populations of Sorex araneus L. III. Interchromosomal recombination in a hybrid zone. Evolution, 45, 1384-1392.

FREDGA, K. 1987. Distribution of chromosome races in Sweden and Denmark. Abstract to the First International Meeting on the Population and Evolutionary Cytogenetics of Sorex araneus, Oxford, UK.

FREDGA, K. AND NAWRIN, J, 1977. Karyotype variability in Sorex araneus $\mathrm{L}$. (Insectivora, Mammalia). Chromosomes Today, 6, 153-161.

GROPP, A. AND WINKING, H. 1981. Robertsonian translocations: cytology, meiosis, segregation patterns and biological consequences of heterozygosity. Symp. Zool. Soc. Lond., 47, 141-181.

GROPP, A., WINKING, H. AND REDJ, C. 1982. Consequences of Robertsonian heterozygosity: segregational impairment of fertility versus male-limited sterility. In: Crosignani, P., Rubin, B. L. and Fraccaro, M. (eds) Genetic Control of Gamete Production and Function, Academic Press, New York, pp. 115-134.

HALKKA, L., SODERLUND, V., SKAREN, U. AND HEIKKILA, J. 1987. Chromosomal polymorphism and racial evolution of Sorex araneus L. in Finland. Hereditas, 106, 257-275.

HANSKI, I. 1986. Population dynamics of shrews on small islands accord with the equilibrium model. Biol. J. Linn. Soc., 28, 23-36.

HANSKI, I. AND KUITUNEN, J. 1986. Shrews on small islands. Epigenetic variation elucidates population stability. Holarctic Ecology, 9, 193-204.

HANSKI, I., PELTONEN, A. AND KASKI, L. 1991. Natal dispersal and social dominance in the common shrew Sorex araneus. Oikos, 62, 48-58.

HAUSSER, J., BOSSHARD, F., TABERLET, P. AND WOJCIK, J. 1991. Relationship between chromosome races and species of Sorex of the araneus group in the western Alps. In: Hausser, J. (ed.) The Cytogenetics of the Sorex araneus Group and Related Topics, Proceedings of the ISACC's Second International Meeting. Mém. Soc. Vaud. Sci. Nat., 19, 79-95.

HEWITT, G. M. AND BARTON, N. H. 1980. The structure and maintenance of hybrid zones as exemplified by Podisma pedestris. Symp. R. Entomol. Soc. Lond., 10, 149-169.
MERCER, S. J. AND SEARLE, J. B. 1991. Preliminary analysis of a contact zone between karyotypic races of the common shrew (Sorex araneus) in Scotland. In: Hausser, J. (ed.) The Cytogenetics of the Sorex araneus Group and Related Topics. Proceedings of the ISACC's Second International Meeting. Mém. Soc. Vaud. Sci. Nat., 19, 73-78.

MERCER, S. J., WALlaCE, B. M. N. AND SEARLE, J. B. 1992. Male common shrews (Sorex araneus) with long meiotic chain configurations can be fertile: implications for chromosomal models of speciation. Cytogenet. Cell Genet., 60, 68-73.

SEABRIGHT, M. 1971. A rapid banding technique for human chromosomes. Lancet, 2, 971-972.

SEARLE, J. B. 1984a. Hybridization between Robertsonian karyotypic races of the common shrew Sorex araneus. Experientia, 40, 876-878.

SEARLE, J. B. 1984b. Three new karyotypic races of the common shrew Sorex araneus (Mammalia: Insectivora) and a phylogeny. Syst. Zool., 33, 184-194.

SEARLE, J. B. 1986. Factors responsible for a karyotypic polymorphism in the common shrew, Sorex araneus. Proc. $R$. Soc. Lond. (B), 229, 277-298.

SEARLE, J. B. 1988. Selection and Robertsonian variation in nature: the case of the common shrew. In: Daniel, A. (ed.) The Cytogenetics of Mammalian Autosomal Rearrangements, Liss, New York, pp. 507-531.

SEARLE, J. B. 1990. A cytogenetical analysis of reproduction in common shrews (Sorex araneus) from a karyotypic hybrid zone. Hereditas, 113, 121-132.

SEARLE, J. B., FEDYK, S., FREDGA, K., HAUSSER, J. AND VOLOBOUEV, V. T. 1991. Nomenclature for the chromosomes of the common shrew (Sorex araneus). In: Hausser, J. (ed.) The Cytogenetics of the Sorex araneus Group and Related Topics. Proceedings of the ISACC's Second International Meeting. Mém. Soc. Vaud. Sci. Nat., 19, 13-22.

SKAREN, U. 1980. The water as a barrier in spreading of shrews. Savon Luonto, 12, 44-47 (in Finnish, English summary).

TEGELSTROM, H. AND HANSEN, L. 1987. Evidence of long distance dispersal in the common shrew (Sorex araneus). Zeitschrift. Saugetierkunde, 52, 52-54.

TEPLOV, v. P. 1943. The significance of the common shrew (Sorex araneus L.) and some other vertebrates in the nutrition of Thymallus thymallus L. Zool. Zh., 22, 366-368 (in Russian, English summary).

woscIK, J. M. 1986. Karyotypic races of the common shrew (Sorex araneus L.) from northern Poland. Experientia, 42, 960-962.

WOJCIK, J. M. AND FEDYK, s. 1985. A new chromosome race of Sorex araneus L. from northern Poland. Experientia, 41, $750-752$. 